\title{
Modern İran edebiyatından metinlerarasılık örneği: Hüzünlü Bahar ${ }^{1}$
}

\section{Esin EREN SOYSAL 2}

APA: Eren Soysal, E. (2019). Modern İran edebiyatından metinlerarasılık örneği: Hüzünlü Bahar. RumeliDE Dil ve Edebiyat Araşttrmaları Dergisi, (Ö6), 427-437. DOI: 10.2900o/rumelide.649268

\section{$\ddot{O} \mathbf{z}$}

Her yazar, şair ve sanatçı, eserlerini ortaya çıkarırken birtakım etkileşimler içerisine girmektedir. Bu etkileşim bazen bir sözün bir şiirde, bir şiirin bir hikâyede ya da resimde yeniden hayat bulmasıyla devam etmektedir. Tüm dünya edebiyatlarında olduğu gibi İran edebiyatında da bu tarz etkileşimleri görmek mümkündür. Zaman zaman geçmişe yönelmeler ve herhangi bir yazar veya şairden etkilenmeler yaşanmaktadır. Hatta bazı yazar ve şairlerin geçmişe sıkı sıkıya bağlı kaldıkları ve bu etkiyle eserlerini ürettikleri görülmektedir. Bu tür eserler ilk olarak Julia Kristeva tarafindan öne sürülen iki veya daha fazla metin arasında oluşturulan bir tür söylem analizi şeklinde adlandırılan "metinlerarasılık" kuramıla değerlendirilmektedir. Böylece metinler belirli bir doğrultuda incelenmekte ve ayrıca okur faktörü ön planda tutulmaktadır. Bu çalışmada da klasik İran edebiyatında önemli bir yeri olan Hâfız Şirâzînnin modern İran şairlerinden neoklasik şair Huşeng İbtihâc'ın şiirlerinden "Hüzünlü bahar" adlı gazelindeki etkileri "metinlerarasıllk" kuramı çerçevesinde değerlendirilecektir. İbtihâc, klasik dönemde kendinden bir simge aramaktadır. O simgeyle şairlikte kendi duygularını beyan etmeyi istemektedir. Dolayısıyla her ne kadar modern bir şair olsa da özellikle Hâfız’a duyduğu fazla ilgiden dolayı Hâfız’ın şiirini detaylıca incelemiştir; bu inceleme sonucunda Hâfız’n anlatım tarzı ve dili, İbtihâc'ın dil ve düşüncesinde çok tesirli olmuştur. Klasik İran edebiyatına bilhassa Hâfız’n gazellerine nasıl bağlı kaldığı "Hüzünlü Bahar” adlı gazelinden elde edilen bulgularla belirtilecektir.

Anahtar kelimeler: Metinlerarasılık, modern İran şiiri, Hâfız Şirazi, Huşeng İbtihâc, gazel.

\section{An example from modern Iranian literature to intertextuality: Hüzünlü Bahar}

\begin{abstract}
Every writer, poet and artist is involved in some interactions while producing his/her works. These interactions sometimes continue when a word comes to life in a poem or when a poem comes to life in a story or painting. It is possible to see such interactions in Iranian literature as in all of the world literature. From time to time, the tendency towards the past and the influence from any writers or poets is detected. Even, it is seen that some writers and poets are strictly tied to the past and produce their works under this influence. These kinds of works are first evaluated by the theory of "intertextuality", which is called a kind of discourse analysis between two or more texts offered by Julia Kristeva. Thus, the texts are examined in a certain direction and the reader factor is prioritized. In this study, the effects of Hâfez Şhirazi, who has an important place in classical Iranian literature, on the ghazel "Hüzünlü Bahar" which is one of the ghazels of the neoclassical poet Hushang Ebtehâj
\end{abstract}

Bu çalışma, Bandırma On yedi Eylül Üniversitesi tarafından 26-28 Eylül 2019'da düzenlenen Uluslararası Akademik Filoloji Çalışmaları Konferansı'nda özet olarak sunulan “Modern İran Edebiyatından Metinlerarasıllk Örneği: “Hüzünlü Bahar" adlı sözlü bildirinin genişletilmiş hâlidir.

2 Dr. Ars. Gör., Karamanoğlu Mehmetbey Üniversitesi, Edebiyat Fakültesi, Mütercim-Tercümanlık Bölümü (Karaman, Türkiye), esineren1336@hotmail.com, ORCID ID: 000o-0002-9957-3452 [Makale kaylt tarihi: 03.10.2019-kabul tarihi: 20.11.2019; DOI: 10.29000/rumelide.649268] 
will be evaluated within the framework of the theory of "intertextuality". In the classical era, Ebtehâj seeks a symbol from his own. He wants to express his feelings in poetry through that symbol. Therefore, he studied the poetry of Hafez in detail due to his curiosity on Hafez much even if he was a modernist poet, as a result of this analysis, the style and language of Hafez was very influential in Ibtihac's language and thought. How his adherence to classical Iranian literature, especially Hafez's ghazels, will be explained by the findings from the ghazel named "Hüzünlü Bahar".

Key words: Intertextuality, modern Iranian poetry, Hafez Şhirazi, Hushang Ebtehâj, ghazel.

\section{Giriş}

Bir etkileşim içerisinde olan edebî metinler, zaman zaman geçmişin izlerini taşırlar. Kimi eserler geçmişe tam anlamıyla bağlıyken kimi eserler bu etkileşimden yeniden bir ben yaratırlar. Eserlerin birbirinden etkilenmesiyle ilgili olarak 1960’lı yıllarda eleştirmen ve yazar Julia Kristeva tarafından "metinlerarasılık” yöntemi öne sürülmüştür. Julia Kristeva’nın yanı sıra Roland Barthes, Michael Riffaterre ve Harold Bloom'un da katkılarıyla metinlerarasılık edebî bir metnin değerlendirilmesinde temel kavramlardan biri hâline gelmiştir. Kristeva, metinlerarasılık kavramını şöyle açıklamaktadır:

"Metinlerarası tek bir metin içerisinde oluşan ve belli bir metinsel yapının farklı kesitlerini (ya da düzgülerini) başka metinlerden alınan çok sayıda kesitin (ya da düzgünün) dönüşümleriymiş gibi algllamamıza olanak sağlayan metinsel bir etkileşim” (Aktulum, 2014: 35).

Bu doğrultuda metinlerarasılığın diğer tanımlarına da yer vermek gerekir. TDK sözlüğü, metinlerarasılık yöntemini, "bütüncül bir yapıya kavuşturulması amacıyla bir edebî metnin dokusuna hem edebiyat alanından hem de başka alanlardan metin parçalarının katılması" (Türkçe Sözlük, 2011: 1667) şeklinde tanımlarken L. Jenny “çok sayıda metnin, anlamın başın çeken bir ana metin ile dönüştürülmesi ve benzeştirilmesi” işi olarak tanımlamakta, G. Genette ise, "bir yapıtla ondan öncekiler ve sonrakiler arasında kurulan ilişkilerin okur tarafindan algılanması” (Uçan, 2016: 75) biçiminde değerlendirmektedir.

Genel olarak belli bir birikimi olan okur tarafından algılanması beklenen metinlerarasılıkta bir ana metin ve diğer etkilenen metinlerin varlığından bahsedilmektedir. Ögeyik bu süreci doğal bir döngü olarak değerlendirmektedir:

"Her metin doğası gereği başka metinlerle veya dıș dünyadaki bildik olgularla ilişki içindedir. Bu bağlamda metinlerarasılık metnin kaçınılmazıdır ve o metnin dokusudur. Metinlerarasılıkla ilgili ortaya konulan görüşler gözden geçirildiğinde, metinlerarasılığın metni oluşturan bir olgu olduğu ve metin incelemelerinin ve eleştirilerinin temelini oluşturduğu göz ardı edilemez” (Ögeyik, 2008: 6).

Metinlerarasılığın metin incelemelerinde kaçınılmaz olduğu görülmekte ve karşılaştırmalı edebiyat alanında da başvurulan bir yöntem olduğu gözlenmektedir.

Aktulum, ilk zamanlarda metinlerin genellikle yazara, yazarın ruhsal durumuna, metnin yazıldığı döneme göre ortaya konduğunu, ancak metinlerin yapısal değişime uğramasıyla çokseslilik özelliği kazanmalarından dolayı sebebiyle yeni bir metin tanımının ortaya çıktığını belirtmektedir. Aktulum'a göre metinlerarasılık yöntemiyle, metin incelemeleri bir bütün içerisinde değerlendirilme firsatı bulup, yeni bir bakış açısı getirilmiştir:

"Metinlerarasının yaratılmasıyla yazardan bölünmüş̧, parçalanmış bir özne anlayışına, bir kaynak ya da etki anlayışından söylemde ayrışık unsurların genel ve belirsiz bir oluş içerisinde olduğu anlayışına, gelişimin sürdüğü anlayışından metnin başka metinlere ait parçaların bir değiş tokuş yeri olduğu, başka metinlere ait gösterge dizgelerinin yeniden dağıtıldığı, ayrışıklık özelliğiyle belirlenen 
bir metin anlayışına geçilir. Metinlerarası olgu, yani her metnin ayrışık söylemlerin ya da başka metinlerin bir kesişme yeri olduğu, her yazının bir çokseslilik niteliğiyle belirdiği, dolaysıyla "metinlerarası postmodern yazının temel özelliklerinden biridir." saptaması eleştirmenler ve yazın kuramcıları arasında artık basmakalıplaşmış, bilinen bir anlayıştı.” (Aktulum, 2014: 9-10).

Aktulum'un da belirttiği üzere metinlerarasılık postmodern düşünceyle de ilişkilendirilmektedir. Metnin bir tarafının geçmişe dayanması ve geçmişin izlerini taşıması da bu ilişkilendirmeyi güçlendirmektedir.

"Postmodern düşünce açısından hiçbir metin daha önce yazılmış metinlerden bağımsız olarak yazılamayacağı görüşüne dayanan metinlerarasılık, postmodern edebiyatın tek bir dünya içinde çeşitlilik/çoğulculuk ve üstkurmaca anlayışının en önemli görünüm ve uygulamalarının başında gelir. Okuyucuya kurmaca bir metin ve dünya ile karşı karşıya bulunduğunu hatırlatan, aynı zamanda metne üst kurmaca niteliği kazandırmanın önemli yöntemlerinden biridir de" (Çetişli, 2013: 181).

Julia Kristeva, bir söylemin diğer söylemlerle ilişki içerisinde olduğunu bu yüzden çokseslilik özelliğinin oluştuğunu belirterek metinlerarasılık kavramını ortaya atmıştır. Böylece Kristeva postmodern olduğu kadar klasik ve modern metinlerin de belirgin özelliklerinden olan ancak klasik eleştirinin yalnızca kaynak ya da köken eleştirisi bağlamında ele aldığı metinlerarasını farklı bir bakış açısıyla eleştiri alanında tanımlamaya girişmiştir (Aktulum, 2014: 12).

Metinlerarasılık her ne kadar modern bir yöntem olsa da geçmişle bağlantılı hareket etmekte, okuru çok yönlü olmaya sevk etmektedir. Öyle ki metinlerarasılık geçmişinin çok eski dönemlere dayandığını söylemek yanlış olmaz. Bu konuda Korkmaz da düşüncelerini "Metinlerarası İlişkilerin Klasik Retorikteki Kökeni Üzerine Bir Araştırma” adlı çalışmasında şöyle dile getirmiştir:

\begin{abstract}
“Metinlerarasılık (intertextuality), genellikle postmodern edebiyat kuramının ilgilendiği ve bir teknik olarak yararlandığı bir kavram olarak görünmektedir. Türk ve dünya edebiyatında metinlerarası tekniğin yeni olduğunu öne sürmek ve bu tekniği sadece postmodern edebiyat kuramlarına özgü kılmak, edebiyat teorisi bağlamında pek çok soruna neden olabilmektedir. Çünkü iktibas, telmîh, irâd-ı mesel ve tazmîn gibi klasik belâgat ilminin öne sürdüğü edebî kavramları bir tarafa bırakmak gelenek ile modern/modern sonrası arasındaki bütün bağları ortadan kaldırmak anlamına gelir” (Korkmaz, 2017: 71).
\end{abstract}

Görüldüğü üzere yöntem her ne kadar yeni gibi görülse de klasik edebiyatta farklı bir surette yer almaktadır. Alıntı bağlamlı edebî sanatlarla metinlerarası bir etkileşim yaşanmaktadır. Dolayısıyla bu etkileşimi sağlayan edebî sanatların kullanımları klasik dönemde de metinlerarasıllı̆ın olduğunu göstermektedir.

Uçan da metinlerarasılığın gelenekle bağlantısı olduğunu, eskiyi bilmenin yeniyi daha iyi değerlendirmeye yardımcı olacağını ve çok yönlü bakış açısı yarattığını düşünmektedir:

"Belli bir geleneğin içinde yer alan ve belli sayıda kaynaklara başvuran bir yapıtın, bu gelenek içerisinde nasıl yer aldığı ve kaynakları nasıl kullandığı çözümlendikten sonra, bir çağa özgü ortak değerler toplamı metinlerarası göndergenin yeniden nasıl okunması gerektiği konusunda okuru yönlendirir, onun aldı̆̆ı yeni anlamların daha iyi açı̆̆a çıkarılmalarına katkıda bulunur” (Uçan, 2016: $85)$.

Eserin geleneğe bağlı olması ve geleneği harmanlayıp okuyucuya modern bir şekilde sunabilmesi birçok açıdan yönlendirici olabilmektedir.

İran edebiyatında da birçok şair ve yazar geleneğe bağlı kalarak eserler ortaya çıkarmışlardır. Geriye dönüş bazen zamanın gerisinde kalmalarına yol açsa da geçmişi takip etmek ve kalıcı eserler üretmek 
çabasına girmişlerdir. Her dönemde olduğu gibi modern İran edebiyatında da eser veren birçok şair, Şirazlı şair Hâfız'dan etkilenmiş, onun etkili ve cezbedici ifadelerini eserlerinde yaratmaya çalışmışlardır. Bu şairlerden biri de Huşeng İbtihâc Sâye'dir. Hâfız’ın divanını detaylı bir şekilde incelemiş ve onun söylemini elde etmeye çalışmıştır. Bu çalışmada öncelikle her iki şairin hayatı hakkında kısa bilgi verilecektir. Farklı çağlarda yaşamış şairlerin hayatları hakkında bilgi edinmenin incelemede yönlendirici olacağı düşünülmektedir. Hâfız’ı İbtihâc'ı ne yönlerden etkilediği birkaç başlıkla ele alınacaktır. Daha sonra Sâye'nin gazellerinden biri olan "Hüzünlü Bahar" gazeli metinlerarasılık yöntemi ile değerlendirilecektir.

\section{Hâfiz Şîrâzî}

Lisan'ul-gayb lakaplı Şemseddin Muhammed Hâfız, 8. yüzyılda yaklaşık H 726 yılında Şiraz'da dünya gelir. Şairin büyükbabası İsfahan köylerinden olan Kuban'dan Fars atabeyleri zamanında Şiraz’a gelir. Babasının ismi Bahaeddin'dir. Babası Şiraz'da ticaret etmekle büyük servet edinir. Annesi Kazurun'ludur. Hâfız hakkında en eski malumat rivayete göre muasırı Gul-endam tarafından yazılmış mukaddimede bulunmaktadır. Bu mukaddimeden şairin, Zamahşeri tefsiri ile Sakkaki'nin Miftah'l, Mutarrizi'nin Misbah'ı ve Matali adlı nahiv kitabı ile meşgul olduğu, Arap şairlerini okuduğu görülmektedir. Şairin mahlasından anlaşıldığı üzere Kur'an'ı 14 türlü kıraat ile ezberlediği, Zamahşari'nin Keşşaf ını tetkik ettiği, muasırı Azud el-din İci'nin telif ettiği Mavakıf adlı meşhur kelam kitabını layığı ile bildiği, zamanın medrese tahsilini tamamlamış olduğu gazellerinden anlaşılmaktadır (Yazıc1, 1997: 103).

Hâfız edip bir kişidir, edebî ve şer’i ilimlere vakıf, felsefi inceliklerden ve irfani gerçeklerden haberdar bir âlimdir. Sözü tüm alanlarda seçici ve özenli, istenilen konuya uygun vezinde, zevkle uyumlu ve her biri çok ince hesaplarla seçilmiş ve olması gereken yere konulmuş kelimelerle doludur. İrfani ve felsefí ince manaları, latif düşünceleri ve ince tefekkürleri en vecizli sözle, en açık ve en doğru şekliyle açıklar. Şiirlerinde söz sanatlarını ustalıkla kullanır (Safâ, 2005: 187).

\section{Huşeng İbtihâc (Sâye)}

1927 yılının İsfend ayında Reşt’te dünyaya gelen İbtihâc'ın mahlası Sâye'dir. (Kanar, 1999:246). Babası Akahan İbtihâc, Reşt’in tanınmış kişilerindendir. İbtihâc ilkokul eğitimini Reşt'te, lise eğitimini Tahran'da yapmıştır. Bir müddet sonra Tahran çimento şirketinin genel müdürü olarak görev almıştır. Sâye, 1971 ve 1977 yılları arasında İran radyosunda "Güller" programının yazmanı ve "Golçîn-i Hefte" adlı müzik programının kurucusu olarak çalışmıştır (Suflî, 2008: 19-23). Halihazırda ailesiyle birlikte Almanya'da yaşamaktadır (aktaran Kırlangıç, 2014: 235).

İbtihâc da başlangıçta Şehriyar gibi Nîmâ yolundan gitmek için biraz çabalar. Fars edebiyatında yenilikçi tarzda eserleri önemli bir yer tutmaktadır. Klasik ve yeni şiirleri arasındaki bağı çok iyi kurmuş, kendi zamanının ruhunu iyi bir şekilde anlamıştır (Alevî, 2007: 305).

İbtihâc hem gazel söyleyen hem de yenilikçi bir şairdir. Şairlik hayatı boyunca bu iki eğilimini paralel olarak korumuştur. İbtihâc'ın gazelleri hem kelimeleri kullanma açısından hem sosyal içeriğe yönelmesi açısından klasik ve modern yeni gazellerin arasında geçit sayılabilir. İbtihâc'in Nîmâî şiire yönelmesi, onun gazellerine nispeten yeni bir renk ve doku kazandırmıştır. Gazelleri içerik açısından toplumcu ve zengin görüşünden dolayı öğreticidir. Anlatım açısından da Sa'dî, Mevlâna, özellikle Hâfız’n 
anlatımından dolayı birleştiricidir. İbtihâc çağdaş dönemdeki seçkin neoklasik gazel seralardan sayllabilir (Rûzbih, 2010: 174).

İbtihâc 1946 yılında eski tarz şiirleri kapsayan Nehostin Na'meler mecmuasını yayımlar. Şair bu mecmuanın şiirlerinin çoğunu klasik tarzda söylemiştir. Eserindeki dilsel bağlam, simgesel ve yapısal düzen tamamen klasik tarza yöneliktir. Bu mecmuada hem âşıane mazmunlar hem de siyasi ve sosyal mazmunları en iyi şekilde kullanmıştır (Zerkânî, 2005: 281).

40'lı yllarda klasik tarzını koruyarak, çeharpare ve Nîmâi kalıbıyla yeni tarzda yazdığı ilk mecmuası Serap’tır (Lengerûdî, 1991: 486). Bu şiir mecmuasının girişinde kendi şiir geçmişini eleştirerek şöyle demiştir:

\begin{abstract}
"Ülkemin özgür insanlarının görüşü demir parmaklılıkların ardında alevlendiğinde, ben aşk ve hevesten bahseden şiirler yazmışım. Yurttaşlarımın sarı ve yıpranmış yüzleri gözyaşı ve kana bulandığında, ben yasemin gülleri için, mehtaplı geceler için, kendi uyku ve rüyalarım için şiir söylemişim. Grup grup erkek, kadın ve çocukları savaş meydanına acı çekerken, ben kendi aşklarıma ağlamışım" (Çâgî, 2005: 166-167).
\end{abstract}

Şair, döneminde yaşanan toplumsal olaylara karşı kendini suçlu hissederek daha sosyal içerikli şiir söylemine yönelmiştir.

50'li yılların başında siyasi çalkantılar ve partici eğilimlerin etkisinde kalarak, bireysel ve âşıane santimantalizmi toplumsal ve siyasi santimantalizme dönüştürerek, siyasi hitabe ve şiirlere yönelmiştir (Lengerûdî, 1991: 587). Sâye sonraki mecmualarında âşıkane şiirleri bırakmış, öfke ve kızgınlık yıllarının ürünü olan Şebgîr adlı şiir kitabıyla sosyal içerikli şiirlere yönelmiştir. Bu şiirlerini siyasi ve sosyal meseleler hakkında tamamen zengin bir düşünce yoğunluğuyla söylediği görülmektedir.

Daha sonra 1955 yılında Zemin adlı mecmuasını yayımlamıştır. Bu mecmuada Zemin ve başka birkaç şiir dışında önceki mecmuasındaki şiirlerinden seçmeler bulunmaktadır. Zemin şiiri bu mecmuanın en meşhur şiiridir. Şair bu şiirde yeni bir mazmun yaratarak yeri, evi, gökten daha üstün daha yüce gösterir. O güne kadar şairlerin hepsi gökyüzünü övgüye laylk görürlerken $O$, yeryüzünü her şeyden daha fazla övgüye layık görür ve insanlığın saygınlığı olarak gösterir (Çâgî, 2005: 179).

Çă̆daş şiirde aydınlık ve yeni bir yol açan Çend Berg ez Yelda 1966 yılında yayınlanmıştır. Şair bu mecmuada tıpkı sembolizm akımı şairleri gibi toplumsal ve sosyal konulara daha çok ilgi göstermiş, ancak romantizmin etkisinden de kurtulamamıştır (Çâgî, 2005: 179). Hem modern edebiyata hem de klasik şiire ilgisi olan şairin her alanda birçok şiiri yer almıştır, belirtildiği üzere kendisini gazel türünde yetkinleştirmeye çalışmıştır.

Bu bağlamda mevcut çalışmada her iki şairin yaşam öykülerine ve edebî yaşamlarına yer verilerek aralarında yüzyıllar olmasına rağmen- etkileşim meydana geldiği, başka bir deyişle klasik gazelin modern gazelde yeniden hayat bulduğu gözlemlenmektedir. Bu oluşumların değerlendirilmesiyle Hâfız’n İbtihâc üzerinde ne açllardan etkili olduğu ve İbtihâc'ın şiirini hangi yönlerden şekillendirdiğini görmek incelemenin temeline katkı sağlamaktadır.

\title{
3. Hâfız Şirâzî’nin Huşeng İbtihâc (Sâye) üzerinde etkileri
}

Modern İran edebiyatı döneminde bir grup şair Nîmâ takipçiliğini yaparken bir grup klasik edebiyatın takipçiliğini yapmıştır. İbtihâc bu iki grubun ortasında kalarak hem kendi dönemiyle ilgilenmiş hem de 
klasik dönemle bilhassa gazelle ilgili çalışmalarda bulunmuştur. Özellikle Hâfız’a duyduğu ilgiden dolayı Hâfız’ın şiirini detaylı bir şekilde incelemiştir. Bu inceleme sonucunda Hâfız’ın anlatım tarzı ve dili, İbtihâc'ın dil ve düşüncesinde tesirli olmaya başlamıştır. Ancak Hâfız dil açısından etkili olsa da şair gazellerinde kendi tarzını oluşturmaya çalışmış ve çağdaş düşüncesini gazellerine yansıtmıştır (Nîkûbaht, 2013: 125). Modern şair olmasının yarattığı canlılık, her ne kadar klasik döneme ait kelime ve terkipleri kullansa da fark edilmektedir.

İbtihâc'ın gazellerinin biçimsel yapısının genelinde fonetik bir denge vardır. Fonoloji ve hece tekrarlarından faydalanarak şiirinde musiki bir düzen oluşturmuştur. Şair sessiz ya da belirli sesli harfleri tekrarlayarak şiirde bir tür musiki oluşturmuştur. Bu kullanım Hâfız’n gazellerinde sıkça görülmektedir. İbtihâc da gazellerinde Hâfız'ın da etkisiyle çeşitli sesli harflerini tekrar ederek kuvvetli bir musiki düzen oluşturmuştur (Tîbe, 2006: 101-118). Bu etkinin önemli sebeplerinden biri, İbtihâc'ın Hâfız’n divanını senelerce araştırması ve ayrıca gazel tarzını da tanımasıdır denilebilir.

İbtihâc'ın Hâfız’dan etkilendiği yönler birkaç başlık altında toplanabilir (Nîkûbaht, 2013: 126-144);

1- Terkipler açısından:

Hâfız’ın gazellerinde bulunan bazı terkipler İbtihâc’ın şiirinde de kullanılmıştır. Bu kullanım bilinçli bir şekilde yapılmıştır.

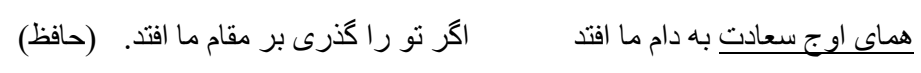

Senin yolun düşerse bizim mekânımıza saadet zirvesinden Hüma düşer tuzağımıza (Kırlangıç, 2012: 117).

$$
\text { هماى او جعادت كه مى كريخت ز خاك شد از امّان زمين دانه جين دام شما (ابتهاج ) }
$$

Topraktan kaçan saadet zirvesinin Hüması yerin emniyetinden dolayı sizin tuzağınızın dane toplayanı oldu (İbtihac).

$$
\text { طبيب عشق مسيحا دم است و مشفق ليك جو درد در نو نبيند كه را دوا بكند (حافظ ) }
$$

Aşk tabibi Mesih nefesli ve müşfiktir, lakin sende dert görmezse kimi tedavi eder (Kırlangıç, 2012: 189).

$$
\text { كه ديد درد مراو دوا دريغ نكرد (ابتهاج) }
$$

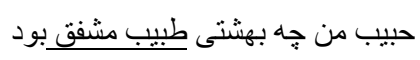

Benim sevgilim hangi cennetin müşfik tabibi ki benim derdimi görür yazık ki devası olmaz. (İbtihâc)

Örneklerden de görüldüğü üzere derin araştırmalarla Hâfız’ın kullandığı terkipler, İbtihâc'ın gazellerinde yer almıştır; ancak bu etkilenme İbtihâc'ın gazellerine şairin kendi tarzıyla yansımıştır.

2- Tabirler açısından:

İbtihâc, Hâfız’ın birçok tabirini şiirinde kullanmıştır. Bu tabirlerin bir kısmını yer yer dağınık bir şekilde

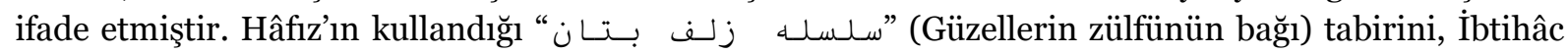

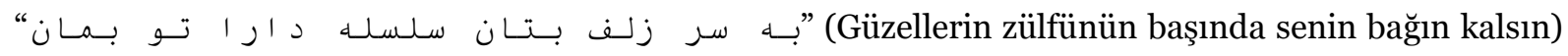
şeklinde dağıtarak kullanmıştır. Bu kullanımla İbtihac'ın hem Hâfız'ın tarzını taklit etmeye hem de kendi modern üslubunu korumaya çalıştı̆̆ı görülmektedir. 
3- Tazmîn ve İktibâs açısından:

İbtihâc'in şiirinde bazen iktibâs ve tazmîn beyti veya Hâfız'ın şiirinden bir mısra görülüyor. Bazen de Hâfız'a karşllık olarak söylediği bir gazelde karineler yer alıyor. Bu yüzden bazen vezin ve kafiye de ortak hale geliyor.

$$
\text { امروز كه در دست تو ام مرحمتى كن فردا كه شدم خاك، جه سود اشك ندامت؟(حافظ) }
$$

Bugün senin elindeyim merhamet et, yarın toprak olunca pişmanlık gözyaşından ne fayda? (Kırlangıç, 2012: 94).

$$
\text { كنون غبار غمم بر فشان ز جهره كه فردا جه سود اشك ندامت كه بر سرم بفشانى؟ (ابتهاج) }
$$

Bugün gam tozumu yüze saçan, yarın başıma pișmanlık gözyașını saçsa ne fayda? (İbtihâc)

4- Vezin-kafiye-redif açısından:

İbtihâc'ın Hâfız'ın şiir musikisini aşırı kullanımı, Hâfız'a olan hayranlığının başka bir göstergesidir. Şiirde musikinin mahfili vezindir. Vezin söze dayalıdır. Bu yüzden iki şairin ortak olan özel bir vezin kullanımı sadece tesir değildir, okuyucuya bu işle kılavuzluk edeceği bir karine de kullanılması gerekir. Sâye kendi şiirinin ihtiyacı gereğince karine seçimini yapmıştır, böylece aruz kurallarına sığdırılan, Hâfız'la ortak olan tabir ve terkipler arasında şiirini üretmiştir.

İbtihâc, gazellerinde her şeyiyle Hâfız’a bağlı kalmaya çalışmış ve üzerindeki bu kuvvetli etkiyi en iyi şekilde yansıtmaya çalışmıştır. Uzun yıllar emek verdiği Hâfız divanını incelemeyle şiirlerinde yeni mazmunlar oluşturmasına da olanak sağlamıştır.

\section{Klasikten moderne metinlerarası bir bakış}

Hâfız’n birçok şairin şiirinde olduğu gibi İbtihâc'ın gazelleri üzerinde de etkileri bulunmaktadır. Aralarında yüzyıllar olmasına rağmen Hâfız modern şairin gazellerinde iz bırakmıştır. Bıraktığı bu izler belirtildiği üzere birçok gazelde görülmektedir. İbtihâc, Hâfız’n divanını detaylı ve uzun yıllar inceleyerek, şairin kullandığı kelime gruplarını, ifadeleri, terkipleri, mazmunları kendi tarzıyla birleştirerek yeniden bir eser ortaya çıkarmaya çalışmıştır. Bu çalışmada da yine Hâfız'ın gazelleri temel alınarak onun izlerini taşıyan İbtihâc'ın "hüzünlü Bahar" adlı gazeli üzerinden değerlendirme yapılacaktır. $\mathrm{Bu}$ değerlendirmede belirli kelime ve terkip alıntıları görüldügüünden, inceleme metinlerarasılığın yöntemlerinden biri olan "alıntı" başlı̆̆ı altında yapılacaktır. "alıntı" yöntemi Aktulum tarafından şöyle tanımlamaktadır:

\footnotetext{
“'Alıntı' metinlerarası ilişkinin en belirtgesel biçimidir. Bir metnin başka bir metindeki varlığını en somut biçimde görünür kılan, ilk akla gelen ve en sık karşımıza çıkan metinlerarası yöntemdir. Genellikle ileri sürülen bir görüşü açlklamak ya da desteklemek için bir yazardan, ünlü bir kişiden alınan parça' olarak tanımlanan alıntı ile bir sözce başka bir bağlamda yinelenir, böylelikle iki ya da daha çok metin arasında bir alışverişe olanak sağlamış olur” (Aktulum, 2014: 76).
}

Alıntı yöntemi bağlamında değerlendirilecek olan gazellerde Hâfız’ın şiirlerine hâkim olan bir okuyucu "Hüzünlü Bahar" gazelindeki Hâfız etkisini rahatlıkla görebilir. Alıntıyı tespit edebilir. 
Hüzünlü Bahar3

1. Ne dudağım gülden açıldı ne gönlüm şarapla öldü

2. Senin yanağına ulaşmayan baharın ne sevinci olur

3. Gönül dağımızın izi açılmış bir laledir.

4. Bu menekşe zülfünün hüznüyle kahrolur.

5. Beklemekten gönlüm kan ağlar

6. Gel, yolunun toprağı lale bahçesi olsun

7. Yeşillerin sevgilileri zülfünün düşüncesiyle baş aşağı

8. Bak ırmak aynasında söğüdün ağlamasına

9. Etrafımızdaki herkesin gönül kanı kadehlerde

10. Kim üzgün sakinin gözünden öpecek

11. Bu sessiz zamanda benim yerim neresi?

12. Senin zulmünden Çoban Yıldızı inler

13. Ömür geçti hâlâ gönle işve satın alıyoruz

14. Siyah akşamın arkasında beyaz sabah vardır

15. Kimin için gölge bu fitnelerde güven sığınağıdır

16. İmanda gönül olduğu zaman ümit vardır

17. Efendinin aynasının sefasına bak bu soğuk anda

18. Kederlenmez ve âşıkların ahına bağışlar.

Bu gazel İbtihâc’ın Siyah Meşk adlı eserinde yer almaktadır. 1960'lı yıllarda söylediği şiirleri kapsayan mecmuası Siyah Meşk (1973) İbtihâc’’n çok sayıda gazellerini içermektedir. Şair kendi gücünü gazel söylemede göstermiştir. Çünkü Sâye, sebk-i Irakî üslubunda söylenmiş gazellere ilgi göstermiş ve bu üslubun en iyi şairlerinden olan Hâfız'nn gazellerini uzun yıllar incelemiştir. Bu yüzden kendisine "Hâfız Zemane" adı verilmiştir (Tîbe, 2006: 101-118).

"Her metin hem bir yeniden okunması hem de vurgulanmasl, yoğunlaştırılmasl, yer değiştirmesi ve derinli olduğu çok sayıda metnin kesiştiği yerde bulunur" (Aktulum, 2014: 9). Şairin 10 beyitten oluşan "Hüzünlü Bahar” gazeli de Hâfız'ın yeniden okunması ve gazelinin bir başka boyuta gelmesi denilebilir. Maşukun hasretiyle yanan bir âşı̆̆ın yakarışını içeren bu gazelde maşuk olmadan ne baharın ne gülün ne de şarabın anlamı vardır. Hâfız’ın 240. Gazelinde de söylediği gibi "Müjde geldi bahar geldi, çimenler yeşerdi diye/Güle şaraba harcarız bir ödenek gelirse" baharın gelmesi sevgilinin gelmesiyle eş değerdir. Sevgilinin gelmesiyle hayat yeniden canlanır, mutluluk neşe olur. 1. ve 2. dizelerde "bahar", "şarap", "gül” motifleriyle klasik dönem şiirine ve Hâfız’ın gazellerine bir gönderme bulunmaktadır. Bunun yanı sıra Hâfız, gazellerinde " مى (şarap)” kelimesi yerine zaman zaman “(şarap)” kelimesini kullanmıştır. Hâfız takipçisi olan İbtihâc da etkilenmesini devam ettirerek " مى (mey- şarap)" kelimesi yerine yine aynı anlama gelen “نبيد(şarap)” kelimesini kullanarak açık bir göndermede bulunmuştur. İbtihâc metinlerarası yöntem açısından Hâfız’ın gazelinden “alıntı” yapmıştır.

Diğer bir alıntı örneğinden bahsedilecek olursak 3. dizede şaire göre yüreğindeki yangının izi öyle güzeldir ki onu bir laleye benzetmektedir. Klasik edebiyatta lalenin ortasında bulunan siyahlık âşığın yüreğinde yer edinen aşk acısına benzetilmektedir. Hâfız da “ نشان(iz, alamet, işaret)” motifini

Gazel, Farsçadan Türkçeye tarafımca tercüme edilmiştir. 
gazellerinde sıkça kullanmıştır. Öncelikle “نشان(iz, alamet, işaret)” motifinin Hâfız’ın gazellerinde nasıl yer aldı̆̆ birkaç dizeyle belirtilecektir;

"Seferdeki yârin izini kime sorayım" (Kurlangıç, 2013: 93),

"Gülün tebessümünde ahde vefadan iz yok" (Kırlangıç, 2013: 44),

"Çene kuyusundan gönül Yusuf unun işareti”" (Kırlangıç, 2013: 281),

"Hak ehlinin nişanı âşıklıktır buna sahip ol” (Kırlangıç, 2013: 357)

Yukarıdaki verilen örnek dizelerde görüldüğüü üzere “ نشان(iz, alamet, işaret)” motifi, çoğu beyitte yer almaktadır. Hâfız arzuladıklarından bir iz, bir işaret aramış ve kendince bir hatıra şekli yaratmıştır. Belki de bu şekilde sevgili onda kalıcı hale gelmektedir. İbtihâc’ı "Gönül dağımızın izi açılmış bir laledir" dizesinde de görüldüğü üzere hem “iz” kelimesi kullanılmış, hem de Hafız’ın söylemi devam ettirilmiştir. Ayrıca dizede yer alan "dağ" ve "lale" kelimelerini kullanarak tenasüp sanatıyla her iki kelime arasında ilişkilendirme yaparak Hâfız'ın tarzını da yansıtmaya çalışmıştır. "Alıntı bir sözcenin bir metinden öteki metne yer değiştirmesi iki metin arasinda bir köprü kurar ve bağ oluşturur” (Aktulum, 2014: 79). Bu dizelerde de açık bir bağ görülmekte, şair kendi modern tarzını klasik tarzla birleştirerek okuyucunun yüzyıllar arasında dolaşmasını sağlamaktadır.

Başka bir “alıntı” örneği “بيا كه (gel)” ifadesidir. Bu ifade Hâfız’ın birçok gazelinde kullanılmıştır. Şair sevgiliye bir seslenme ihtiyacı duymaktadır. Maşukunu beklemekte ve gazellerinde ona seslenmektedir. Öncelikle Hâfız’ın gazel örnekleri üzerinden bu ifadeyi değerlendirmek gerekirse her defasında başka başka sebepler göstererek aslında gelmesini istemektedir;

"Gel, emel sarayının temeli son derece gevşektir" (Kırlangıç, 2013: 43),

"Gel ey şimal rüzgârı, kurban olayım güzel kokunu" (Kırlangıç, 2013: 304),

"Gel, feleğin Türk’ü yağmaladı oruç sofrasını" (Kırlangıç, 2013: 134),

"Gel, meyhanenin gayb elçisi dün gece bana" (Kırlangıç, 2013: 267),

İbtihâc da “بيا كه(gel)” ifadesini "Hüzünlü Bahar” gazelinde kullanmıştır. O da maşuka seslenmekte, onun yolunu gözlemektedir. Hâfız’n da etkisiyle sevgilinin gelmesiyle her şeyin düzeleceğini, tabiattaki her varlığın mutlu olacağını belirtmektedir. Onun hüznüyle çiçekler kahrolmakta, yeşillikler ters dönmektedir Şair gazelin devamında söğüdün ırmağa bakarak ağlamakta olduğunu, maşukun zulmünden Çoban Yıldızının inlediğini ve bu kederle kadehlerin kanla dolduğunu, sakinin de üzüldüğünü belirtmektedir. Ancak şair bu günlerin geçeceğini, karanlıktan aydınlığa çıkılacağını ifade etmektedir. İman ve inanç dolu bir göğüste ümit olacağını söylemektedir. Şair aşk yolunda çile çekmektedir. Hâfız'ın 240. Gazelinin 7. ve 8. dizelerinde de belirtildiği gibi "Kederden şikâyet etme, çünkü talep yolunda/Rahata eremez zahmet çekmeyen kimse" aşk yolunda çekilen acılar mübahtır. Tasavvufta "çile" mertebesinde çekilen acılar ile sevgilinin yolunda çekilen sıkıntılar birbirine benzetilmektedir. Bu doğrultuda eğer âşık maşuka ulaşmak istiyorsa çile çekmeli ve bundan şikâyet etmemelidir.

Gazelin 17. dizesinde yer alan “خواجه(efendi)” kelimesi de Hafız’n gazellerinden etkilenmenin bir belirtisidir.

"Ah Efendi, dert yok ama tabip var" (Kırlangıç, 2013: 69),

"Dedi yanlışın var efendi, vefa olmaz bu ahde" (Kırlangıç, 2013: 74),

"Efendi, beni tekkede tekrar göreceğin günler geçti” (Kırlangıç, 2013: 115), 
“Efendim âşık olduğumu anladı da bir şey demedi” (Kırlangıç, 2013: 230),

Hâfız gazellerinde sık sık "efendi" kelimesini kullanmıştır. Gazellerinde kullandığı bu kelimeyle bir yöneticiye, bir Emire ya da padişaha göndermede bulunmaktadır. İbtihâc da bu gazelinde "efendi" kelimesini kullanmıştır. Yine bu kelimede Hâfız’n etkisi görülmektedir. Ancak şairin herhangi bir yöneticiye göndermede bulunup bulunmadığına ulaşlamamıştır.

\section{Sonuç}

Hafız yüzyıllardır İran edebiyatını etkileyen güçlü bir şair olmuştur. Söylemi ve dili etkili, gazelleri ayrıntılı ve düşündürücüdür. Şairin eserlerinde kelimeleri kullanışı ustacadır. İran edebiyatındaki çoğu şair, Hafız’ın söylemini taklit etmeye, onun yazdığı gazeller gibi gazel ortaya çıkarmaya çalışmıştır. Ancak bazı şairler Hâfız’ın taklitçisi olmaktan öteye gidemezken bazı şairler Hâfız'ın gazellerini sentezleyerek kendi söylemlerini oluşturmuşlardır. Bunu başarabilen şairlerden birisi de Huşeng İbtihâc'dır. Yıllarca Hâfız’ın gazelleri üzerinde çalışmış ve kendince bir tarz elde etmiştir. Söylemi sağlam, dili cezbedici olmuştur. Farklı yüzyıllarda yaşamış olsalar da İbtihâc'ın eserlerinde Hâfız bir iz bırakmıştır. Her iki şairin şiirini okuyan bir okuyucu "Hüzünlü Bahar" gazelinde yer alan "gül”, "şarap", "saki", "fitne", "lale" ve daha birçok kelime sayesinde Hâfiz etkisini hemen hisseder, tamlamaların kuruluşu, "dağ" ve "lale", "zülüf" ve "söğüt" kelimeleri gibi birbirine yakın ya da çağrışım sağlayan kelimelerin ve vezin dışında içsel bir musikinin varlığı Hâfız’ın gazellerini anımsatmaktadır. Kaynak metin olarak değerlendirilecek olan gazel de izlek gül ile bülbülün aşkına istinaden, âşı ve maşukun ilişkisi ele alınmış, aşk yolunda "çile" çekme mazur görülmüştür. Gazelde "gül, şarap, saki, bülbül” gibi motifler kullanılmış, gazel bu motifler çerçevesinde oluşmuştur.

Bu tür çalışmalar klasik çalışmaların modern eserler üzerinde nasıl bir etki bıraktığını görmek açısından önem arz etmektedir. İnceleme esnasında da belirtildiği üzere "metinlerarasılık" yöntemi doğrultusunda "alıntı-gönderge" yöntemi ele alınmış ve değerlendirmeler yapılmıştır. Geçmiş dönem şairinin modern bir şairi ve şiirini nasıl etkilediği gözlenmiştir.

\section{Kaynakça}

Aktulum, K. (2014). Metinlerarası İlişkiler. Ankara: Kanguru.

Bozorg, A. (2007).Târîh u Tehavvulât-i Edebiyat-i Muâsır-ı Fârsî (Nazm u Nesr). Tahran.

Cağferî, T. (2006). Ber resi-yi Sâhtarî Surî-yi Zebân-i Gazelhâ-yi Hûşeng İbtihâc. Kâveşnâme Zebân u Edebiyât-i Fârsî, Sonbahar-Kış, 13, 101-118.

Çâgî, A. H. (2005). Ceryânhâ-yi Ş’irî-yi Muâsır-ı Fârsî Ez Kûd ta İnkılab. Tahran: Emîr Kebîr.

Çetişli, İ. (2013). Batı Edebiyatında Edebî Akımlar, Ankara: Akçă̆.

Kanar, M. (1999). Çağdaş İran Edebiyatının Doğuşu ve Gelişmesi. İstanbul.

Kırlangıç, H. (2013), Hâfız Divanı, İstanbul: Kapı.

Kırlangıç, H. (2014), Meşrutiyetten Cumhuriyete İran Şiiri, Ankara: Hece.

Korkmaz, F. (2017). Metinlerarası İlişkilerin Klasik Retorikteki Kökeni Üzerine Bir Araştırma, HikmetAkademik Edebiyat Dergisi, Gelenek ve Postmodernizm Özel Sayısı, Yıl:3, 71-88.

Lengerûdî, Ş. (1991). Târîh-i Tahlîlî-yi Şiłr-i Nov, Tahran: Merkez.

Muhammedî, H. ; Nîkûbaht, N. (2013). Berresi-yi Mukâyese-yi Ş’ir-i Hâfiz u Hûşeng İbtihâc (Sâye), Kâveşnâme Zebân u Edebiyât-i Fârsî, Bahar-Yaz, 26, 121-146.

Ögeyik, M. C. (2008). Metinlerarasılık ve Yazın Eğitimi. Ankara: Anı. 
Rûzbih, M. R. (2010). Edebiyât-i Muâsır-ı İran (Şiir). Tahran: Rûzgâr.

Safâ, Z. (2005). İran Edebiyatı Tarihi. C. 2.Ankara: Nüsha.

Suflî, S. S. (2008). Ey Aşk Heme Behane Ez To Est Nakd ve Tahlil ve Gozide-Yi Eş’ar-İ Emîr Huşeng İbtihâc Sâye. Tahran: Sohen.

Türkçe Sözlük (2011) Ankara: Türk Dil Kurumu.

Uçan, H. (2016). Yazınsal Eleştiri ve Göstergebilim (Kuram, Uygulama, Çözümleme Örnekçeleri). İstanbul: İz.

Zerkânî, S. M. (2005). Çeşm Endaz Ş’ir-i Muâsır-ı İran. Tahran: Sâles.

Yazıcı, T.(1997). Hâfız-ı Şîrâzî, TDV İslam Ansikloğpedisi, C.15, 103-106. 